\title{
Rhamnolipid production from waste cooking oil using newly isolated halotolerant Pseudomonas aeruginosa M4
}

Juan Shi ${ }^{\mathrm{a}, \mathrm{c}}$, Yichao Chen ${ }^{\mathrm{a}}$, Xiaofeng Liu ${ }^{\mathrm{a}}$, Yi Ran ${ }^{\mathrm{b} *}$, Dong Li $\mathrm{i}^{\mathrm{a}, \mathrm{b}}$

${ }^{\mathrm{a} K e y ~ L a b o r a t o r y ~ o f ~ E n v i r o n m e n t a l ~ a n d ~ A p p l i e d ~ M i c r o b i o l o g y, ~ E n v i r o n m e n t a l ~ M i c r o b i o l o g y ~ K e y ~}$ Laboratory of Sichuan Province, Chengdu Institute of Biology, Chinese Academy of Science, Chengdu 610041, China;

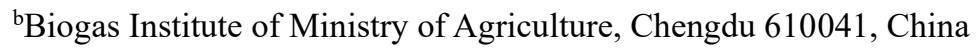

'University of Chinese Academy of Sciences, Beijing 100049, China;

* Corresponding author

E-mail address:

biogas_ranyi@163.com

lidong@cib.ac.cn 


\begin{abstract}
This study isolated a novel halotolerant Pseudomonas aeruginosa M4, that was able to degrade oil and produce rhamnolipids. Various carbon sources, nitrogen sources, inoculum ratio, $\mathrm{pH}$, and temperature were tested to optimize the oil degradation conditions. The highest oil degradation rate of $85.20 \%$ and lipase activity of $23.86 \mathrm{U} / \mathrm{mL}$ were obtained under the optimal conditions $(5 \%$ inoculum at $35^{\circ} \mathrm{C}$ and $\mathrm{pH} 8$ ). The components of degradation products at different times were analyzed to explore the mechanism of oil degradation by GC-MS. Short chain fatty acid of acetic and n-butyric acids were the primary degradation intermediates. P. aeruginosa M4 had good salt tolerance up to $70 \mathrm{~g} / \mathrm{L}$. The maximum rhamnolipid concentration of $1119.87 \mathrm{mg} / \mathrm{L}$ was produced when $P$. aeruginosa $\mathrm{M} 4$ used waste cooking oil as the sole carbon source. Rhamnose precursors were synthesized from glycerol, a hydrolysis product of waste cooking oil. R-3-hydroxyalkanoate precursors were synthesized de novo using acetylCoA produced from $\beta$-oxidation of fatty acids. The findings show that $P$. aeruginosa M4 is a valuable biosurfactant producer in the treatment of waste cooking oil.
\end{abstract}

Keywords Waste cooking oil $\cdot$ Rhamnolipid $\cdot$ Salt tolerance $\cdot$ Lipase $\cdot$ Pseudomonas aeruginosa

Key Points P. aeruginosa isolation, oil degradation mechanism, rhamnolipid production from WCO 


\section{Introduction}

Food waste (FW) grows steadily every year. Untreated FW causes serious environmental problems, including soil pollution, odor production, and pest attraction. Therefore, FW management is an urgent need worldwide, with a growing emphasis on resource recovery and environmental protection promoting the rapid adoption of novel technologies in this field (Zhang et al. 2010; HKEPD 2015). The composition of FW is highly heterogeneous, but mostly includes (w/w) 40-60\% starch, 5-10\% protein, $0.84-1.38 \%$ salt, and 10-40\% fatty or oily contents (Pleissner et al. 2013; Demichelis et al. 2017). In general, fatty or oily waste products, specifically waste cooking oil (WCO), can be separated and collected from the FW (Patil et al. 2012).

FW management currently includes landfilling, incineration, and biological treatments like composting, anaerobic digestion, or transformation to animal feed (Wang et al. 2013; Kiran et al. 2015; Chan et al. 2016; Pleissner et al. 2017). Landfilling and incineration are rarely used because of the high water content of FW, and when FW is used as animal feed, its ingredients are transferred into the food chain, affecting the entire ecosystem and ultimately influencing human health (Chen et al. 2009; Lan et al. 2015). Biological treatment of FW is challenging because of the large amounts of oil in it. In many cases, an oil layer will form on the surface of the FW preventing the diffusion of oxygen, which reduces composting efficiencies. Oil also poses a barrier to anaerobic digestion because of its inhibitory effects on anaerobic microorganisms and high rates of digester foaming (Awasthi et al. 2018; Cammarota and Freire 2006).

One of the most economic and environmentally friendly approaches to dealing with FW was to use the WCO to produce biosurfactants (Sharma et al. 2019; Maddikeri et al. 2015; Thavasi et al. 2007). Biosurfactants can emulsify hydrophobic hydrocarbons, enhancing their solubility in water and reducing surface tension. In addition, biosurfactants have much lower toxicity and higher biodegradability, structural diversity, and surface activity than chemical surfactants (Dobler et al. 2016). However, few studies have focused on biosurfactant production using WCO as the sole carbon source, probably because of differences in the quality of WCO from different sources (Pansiripat et al. 2010). To date, most reports on biosurfactant production from WCO have been less than remarkable with maximum oil degradation achieved almost a week later (Gudina et al. 2013; Rabiei et al. 2013). 
The purpose of this study was to isolate a highly efficient oil degrading strain that can produce biosurfactants. Soybean oil was used as the limiting carbon source to evaluate the oil degrading ability of strains. The conditions for oil degradation (carbon source, nitrogen source, inoculum, temperature, and initial $\mathrm{pH}$ ) were optimized. GC-MS was used to analyze the degradation products at various time points to explore the mechanism of oil degradation. The ability of the strain to produce biosurfactants and resist salt stress was also investigated using WCO as the sole carbon source.

\section{Materials and methods}

\section{Samples and culture medium}

Soil samples were collected from an FW treatment plant and used to isolate target microorganisms. Nutrient broth (NB) (seed medium) contained beef extract $5.0 \mathrm{~g} / \mathrm{L}$, tryptone $10.0 \mathrm{~g} / \mathrm{L}$, and NaCl $5.0 \mathrm{~g} / \mathrm{L}$. For the preparation of nutrient agar plates and slants, $15 \mathrm{~g} / \mathrm{L}$ agar (strength 1300) was also added to the NB. Mineral salt medium (MSM) contained $\left(\mathrm{NH}_{4}\right)_{2} \mathrm{SO}_{4} 5.0 \mathrm{~g} / \mathrm{L}, \mathrm{K}_{2} \mathrm{HPO}_{4} 2.0 \mathrm{~g} / \mathrm{L}, \mathrm{KH}_{2} \mathrm{PO}_{4} 2.0 \mathrm{~g} / \mathrm{L}$, $\mathrm{MgSO}_{4} 0.5 \mathrm{~g} / \mathrm{L}, \mathrm{NaCl} 2.0 \mathrm{~g} / \mathrm{L}, 2 \mathrm{~mL}$ trace element solution $\left(\mathrm{ZnSO}_{4} \cdot 7 \mathrm{H}_{2} \mathrm{O} 0.66 \mathrm{~g}, \mathrm{MnCl}_{2} \cdot 4 \mathrm{H}_{2} \mathrm{O} 0.44 \mathrm{~g}\right.$, $\mathrm{H}_{3} \mathrm{BO}_{4} 0.02 \mathrm{~g}, \mathrm{CoCl}_{2} \cdot 6 \mathrm{H}_{2} \mathrm{O} 0.40 \mathrm{~g}, \mathrm{CuCl}_{2} \cdot 2 \mathrm{H}_{2} \mathrm{O} 0.01 \mathrm{~g}, \mathrm{NiCl}_{2} \cdot 6 \mathrm{H}_{2} \mathrm{O} 0.61 \mathrm{~g}, \mathrm{NaMoO}_{4} \cdot \mathrm{H}_{2} \mathrm{O} 0.73 \mathrm{~g}$, EDTA $0.01 \mathrm{~g}$, and $1 \mathrm{~L}$ deionized water). Oil degradation medium was prepared by adding soybean oil to $1 \mathrm{~L}$ MSM. Rhamnolipid production broth comprised WCO and 1 L MSM. The pH of all the media was adjusted to 7 using $1 \mathrm{~N} \mathrm{NaOH}$ and $1 \mathrm{~N} \mathrm{HCl}$ and autoclaved at $121^{\circ} \mathrm{C}$ for 20 min before use.

The fatty acids in soybean oil used in this study primarily contains $1984 \mathrm{mg} / \mathrm{L}$ and $8848 \mathrm{mg} / \mathrm{L}$ of palmitic and linoleic acids, respectively.

\section{Isolation and identification of oil degrading strains}

The isolation and identification protocols were modified from those described by Zhang et al (2012). Briefly, about $10 \mathrm{~g}$ of each soil sample was added to a flask containing sterile glass beads and sterile water. Following mixing, $10 \mathrm{~mL}$ of the supernatant was inoculated into enriched culture medium and incubated at $35^{\circ} \mathrm{C}$ and $180 \mathrm{rpm}$ until the oil was degraded. Thereafter, the oil concentration in the medium was gradually increased $(5,10,15,20$ and $25 \mathrm{~g} / \mathrm{L})$ every 6 days. One milliliter of the last acclimated bacterial solution was diluted in a gradient, and the $10^{-5}, 10^{-6}$, and $10^{-7}$ bacterial solutions were spread on 
lipase screening plates and inverted in a biochemical incubator for 1-3 days. Large and bright red colonies were then picked and inoculated in seed medium. The seed broth was then inoculated at $5 \%(\mathrm{v} / \mathrm{v})$ into re-screening medium with soybean oil as the only carbon source and cultured for 3 days. The residual oil, lipase activity, and cell density of the fermentation broth were measured to evaluate the oil degrading ability of the isolated strains. The strain with the highest soybean oil degradation ability was then selected and incubated on agar slant medium, cultured at $35{ }^{\circ} \mathrm{C}$ for $24 \mathrm{~h}$, and stored at $4{ }^{\circ} \mathrm{C}$ for the next set of evaluations. This strain was then identified using phylogenetic analysis, physiological and biochemical identification, and 16S rDNA sequencing. Morphological characteristics were evaluated using a scanning electron microscope. 16S rDNA sequence analysis was performed using universal primers $27 \mathrm{~F}$ (seq) and 1492R (seq). These sequences were then compared with known 16S rDNA sequences using BLAST, and phylogenetic analysis was constructed using the Neighbor-Joining method in MEGA version 6.0 software (Dastager et al. 2009).

\section{Optimization of oil degradation conditions}

We used a systematic approach to evaluate all the nutrient and physical parameters in the oil degradation assays (Kantak et al. 2011). All selected strain inoculums were prepared from NB medium after incubation at $35{ }^{\circ} \mathrm{C}$ for $20 \mathrm{~h}$. The optimization experiments were all conducted in $150 \mathrm{~mL}$ Erlenmeyer flasks with $30 \mathrm{~mL}$ culture medium at $35^{\circ} \mathrm{C}$ and $180 \mathrm{rpm}$. In this analysis, we evaluated two nutrient and three physical parameters to create the optimal culture conditions for oil degradation. These parameters included carbon source (soybean oil, glucose, fructose, malt extract powder, sucrose, and soluble starch), nitrogen source $\left(\left(\mathrm{NH}_{4}\right)_{2} \mathrm{SO}_{4}, \mathrm{NaNO}_{3}\right.$, urea, tryptone, and yeast extract), inoculum ratio $(2-10 \%, v / v)$, temperature $\left(25-60{ }^{\circ} \mathrm{C}\right)$, and $\mathrm{pH}(4-10)$. After 3 days of fermentation, the cell density in the fermentation broths was measured, and the lipase activity of the fermentation supernatant was determined. The fermentation supernatant was obtained by centrifuging the fermentation broth at 8000 rpm for $10 \mathrm{~min}$ to remove bacterial cells and residual oil.

The oil degradation characteristics of the selected stain was evaluated after 5 days of fermentation carried out at the optimized conditions. Both cell growth and $\mathrm{pH}$ of the fermentation broth were observed during this time frame. Cell growth was monitored by optical density at $600 \mathrm{~nm}$, and pH was recorded using a pH meter at $24 \mathrm{~h}$ intervals. The oil degradation rate and lipase activity of the fermentation broth 
were also measured every $24 \mathrm{~h}$. Then, cell density, $\mathrm{pH}$ value, oil degradation rate, and lipase activity were plotted against time.

\section{Kinetics of rhamnolipid production}

To study the kinetics of rhamnolipid production, the selected strain was inoculated into the fermentation medium and cultivated at $35^{\circ} \mathrm{C}$ and $180 \mathrm{rpm}$. WCO was the only carbon and energy source in this fermentation medium, and its concentration was $5 \mathrm{~g} / \mathrm{L}, 10 \mathrm{~g} / \mathrm{L}$, and $25 \mathrm{~g} / \mathrm{L}$. Samples were harvested every $24 \mathrm{~h}$ until reaching $132 \mathrm{~h}$ and analyzed for cell density, lipase activity, rhamnolipid concentration, and $\mathrm{pH}$.

\section{Salt tolerance assessment}

Seed solution with the selected strain was inoculated into the medium with a salt concentration of $0,2,5,10,15,20,25,30,50,70,100$, and $150 \mathrm{~g} / \mathrm{L}$. In this experiment, uninoculated culture medium was used as a control, and the $\mathrm{OD}_{600}$ value of the culture medium was measured over time. The range of salt concentrations tolerated by the experimental strain was determined by the change in $\mathrm{OD}_{600}$ value.

\section{Analytical methods}

\section{Measurement of cell density}

Optical density was used to approximate cell density. A small amount of the fermentation broth was taken and divided into two groups, one which was centrifuged at $8000 \mathrm{rpm}$ for $10 \mathrm{~min}$, and the supernatant collected and used as the control, and the other was measured as the sample. The sample and the supernatant were diluted with sterile water to facilitate OD reading, and their optical density at 600 $\mathrm{nm}\left(\mathrm{OD}_{600}\right)$ was determined by a spectrophotometer. The cell density was obtained by subtracting the optical density of the supernatant from the optical density of the sample.

\section{Determination of lipase activity}

Lipase activity was determined spectrophotometrically by measuring incremental changes in the absorption at $405 \mathrm{~nm}$ promoted by the hydrolysis of p-NPC (Reddy et al. 2016). The reaction mixture 
was composed of $0.7 \mathrm{~mL}$ of $0.05 \mathrm{M}$ phosphate buffer $(\mathrm{pH} 8.0), 0.1 \mathrm{~mL}$ of p-NPC substrate solution, and $0.2 \mathrm{~mL}$ of diluted enzyme sample. It was incubated at $35^{\circ} \mathrm{C}$ for $5 \mathrm{~min}$, and then $1 \mathrm{~mL}$ of ethanol was added to terminate the reaction. The absorbance of resulting yellow product was measured at $405 \mathrm{~nm}$. The substrate solution containing $32 \mu \mathrm{L}$ p-NPC and $10 \mathrm{~mL}$ 2-propanol was prepared fresh for each round of analysis. One international unit of lipase activity was defined as the amount of enzyme needed to catalyze the release of $1 \mu \mathrm{mol}$ of $\mathrm{p}$-NP per minute from p-NPC under these conditions (Pacheco et al. 2012).

\section{Determination of oil degradation rate}

Residual cooking oil content in the fermentation broth after incubation was quantified by infrared spectrophotometry. In accordance with the national standard for the determination of animal and vegetable oils, the remaining oil in the fermentation medium was extracted using an equal volume of tetrachloromethane. After mixing, the solution formed a stable upper aqueous phase and lower organic phase, and the lower organic phase was collected and diluted with tetrachloromethane. Then, $10 \mathrm{~mL}$ of this was taken and analyzed by an infrared spectrometer.

The oil content extracted from the control group was used as the initial oil concentration. The oil degradation rate was calculated by subtracting the oil content extracted from the experimental group from the initial oil content. This calculation can be represented by the following formula (1):

$$
\text { Oil degradation rate }(\%)=\frac{\text { initial oil concentration }- \text { residual oil concentration }}{\text { initial oil concentration }} \times 100 \%(1)
$$

\section{Analysis of fatty acids produced during oil degradation}

The supernatants from the fermentation broths were collected and freeze-dried at various time points $(0,12,24,36,48,72$, and 96 h). These samples were sent to the Shanghai Minxin Biotechnology Co., Ltd. for fatty acid composition and content evaluation. The pretreatment for the determination of shortchain fatty acid content included the following steps: A sample of $300 \mu \mathrm{L}$ was placed in a $1.5 \mathrm{~mL}$ centrifuge tube, then $115 \mu \mathrm{L}$ sulfuric acid $(50 \%)$ and $450 \mu \mathrm{L}$ ether $(20 \mu \mathrm{g} / \mathrm{mL})$ containing an internal standard were added. This solution was mixed by vortex for $2 \mathrm{~min}$ and then placed into a centrifuge at $4{ }^{\circ} \mathrm{C}$ and run at $12,000 \mathrm{rpm}$ for $20 \mathrm{~min}$. Tubes were then placed at $4{ }^{\circ} \mathrm{C}$ for $30 \mathrm{~min}$, and the supernatant was draw and used for GC-MS analysis (Radzuan et al. 2017). The pretreatment method for the 
determination of medium-long-chain fatty acids included the following steps: $1 \mathrm{~mL}$ of sample was added to a $10 \mathrm{~mL}$ centrifuge tube, then $2 \mathrm{~mL}$ of $10 \%$ acetylchloromethanol solution and $1 \mathrm{~mL}$-hexane were added, and the mixture was reacted at $95{ }^{\circ} \mathrm{C}$ for $2 \mathrm{~h}$ with oscillation every $5 \mathrm{~min}$. After removal, it was cooled to room temperature, and $6 \mathrm{~mL}$ of $6 \%$ potassium carbonate was added. After centrifugation at $4000 \mathrm{rpm}$ for $10 \mathrm{~min}$, the supernatant was placed in a new $1.5 \mathrm{~mL}$ centrifuge tube and nitrogen was blown. $100 \mu \mathrm{L}$ of $\mathrm{n}$-hexane and $5 \mu \mathrm{L}$ of the internal standard were added prior to redissolution. After centrifugation at $3000 \mathrm{rpm}$ for $5 \mathrm{~min}, 100 \mu \mathrm{L}$ of the supernatant was taken for evaluation.

\section{Rhamnolipid determination}

The culture medium was first centrifuged at $8000 \mathrm{rpm}$ for $10 \mathrm{~min}$ to remove cells for the quantitative analysis of rhamnolipid content. Five milliliters of the supernatant were then extracted with $15 \mathrm{~mL}$ of ethyl acetate. The upper organic phase was collected and evaporated until dry, and the rhamnolipid residues were dissolved in $2 \mathrm{~mL}$ of water. Rhamnolipid concentration in the cultivation medium was measured using the anthrone-sulfuric acid colorimetric method at $625 \mathrm{~nm}$ (Zhu et al. 2012), and the rhamnose value was calculated according to the L-rhamnose (20-100 mg/L) standard curve. The concentration of rhamnolipids was determined by multiplying the rhamnose value by a coefficient of 3.4, which was derived from the correlation of pure L-rhamnose (Benincasa et al. 2002). The anthronesulfuric acid solution was prepared by dissolving $0.1 \mathrm{~g}$ anthrone in $50 \mathrm{~mL}$ concentrated sulfuric acid solution.

\section{Results}

\section{Isolation and characterization of oil degradation strains}

Twenty-two bright red colonies were observed on the lipase screening plates after incubation at $35{ }^{\circ} \mathrm{C}$ for 1-3 days. After purification, the colonies were inoculated into the re-screening medium with soybean oil as the sole carbon source and incubated at $35^{\circ} \mathrm{C}$ for three days. Only five strains were shown to grow well in the re-screening medium (Table 1). Strain M4 was chosen for further analysis as it had the highest growth rate, lipase activity, and oil degradation rate.

Physiological identification showed that M4 could grow well in a temperature range between 25 
and $40^{\circ} \mathrm{C}$, with an optimum temperature at $35^{\circ} \mathrm{C}$; $\mathrm{pH}$ range was determined to be between 5 and 9 , and the optimum value was 6 . The morphological characteristic of M4 indicated by scanning electron microscope was shown in Fig. 1a, where M4 is a rod-shaped bacillus with a length of about $2.44 \mu \mathrm{m}$ and a width of about $0.78 \mu \mathrm{m}$. A phylogenetic tree was constructed based on the $16 \mathrm{~S}$ rDNA sequence (1400 bp) analysis using the Neighbor-Joining method (Fig. 1b). This analysis suggests that M4 is a strain of Pseudomonas aeruginosa, and BLAST analysis showed a 99\% sequence similarity between this strain and P. aeruginosa DSM 50071.

\section{Optimization of oil degradation conditions for $P$. aeruginosa M4}

\section{Carbon and nitrogen sources}

Different carbon sources can influence strain growth and lipase production. In this study, $P$. aeruginosa M4 was shown to have maximum lipase activity $(11.20 \mathrm{U} / \mathrm{mL})$ when soybean oil was available as a primary carbon source (Fig. 2a). Malt extract produced the highest biomass for $P$. aeruginosa M4, but despite this high biomass, lipase activity was relatively low, suggesting that in $P$. aeruginosa M4, lipase is inducible under specific growth conditions.

The various nitrogen sources tested in this study $\left(\left(\mathrm{NH}_{4}\right)_{2} \mathrm{SO}_{4}, \mathrm{NaNO}_{3}\right.$, urea, tryptone and yeast extract), the lipase activity and cell growth levels were highest (16.90 U/mL and 2.17, respectively) when tryptone was added to the fermentation medium (Fig. 2b). Burkholderia spp. displays a similar preference for tryptone when producing lipases (Gupta et al. 2007).

\section{Inoculum ratio, temperature, and pH}

The effect of the inoculum ratio on lipase activity was shown in Fig. 2c. The optimal inoculum value was shown to be $5 \%(\mathrm{v} / \mathrm{v})$, as we observed significant growth inhibition when the inoculation ratio rose. Therefore, an inoculum ratio of 5\% (v/v) was used in all the evaluations in following studies.

The lipase activity at different temperatures $\left(25-45^{\circ} \mathrm{C}\right)$ was determined. The highest lipase activity (19.87 U/mL) was obtained at $35^{\circ} \mathrm{C}$ (Fig. 2d). But lipase activity steadily decreased as the temperature approached $45^{\circ} \mathrm{C}$.

The effect of $\mathrm{pH}$ was caused by protonation or deprotonation of participating molecules in one or more reaction steps (Taylor et al. 2002). Changes in the $\mathrm{pH}$ of the medium resulted in changes in lipase 
activity with the best activity $(26.65 \mathrm{U} / \mathrm{mL})$ observed at $\mathrm{pH} 8$ and the worst activity at $\mathrm{pH} 4$ (Fig. 2e).

Previous studies have shown that P. aeruginosa and Bacillus licheniformis had the highest lipase activity at a pH between 7.0 and 10.0 (Mobarak et al. 2011; Sharma et al. 2011).

\section{Potential mechanism of oil degradation by $P$. aeruginosa M4}

P. aeruginosa M4 was continuously cultured under optimum conditions in a fermentation medium supplemented with $20 \mathrm{~g} / \mathrm{L}$ soybean oil as the sole carbon and energy source. The oil degradation rate, cell density, lipase activity, and $\mathrm{pH}$ of these fermentation broths are shown in Fig. 3. The oil degradation rate, cell density, and lipase activity increased with longer fermentation times. This was consistent with a previous report (Feng et al. 2017) of a similar trend. The decrease in $\mathrm{pH}$ over time may be related to the degradation of soybean oil and the production of fatty acids. During the $96 \mathrm{~h}$ fermentation, the oil degradation rate reached more than $85.20 \%$, the cell density at $\mathrm{OD}_{600}$ was 2.32 , and the lipase activity was $23.86 \mathrm{U} / \mathrm{mL}$. The $\mathrm{pH}$ of the fermentation broth was lower than 5.3. With longer fermentation time, the accumulation of fatty acids and acidification of the fermentation broth negatively affected the growth and lipase activity of the strain, and the oil degradation rate was also reduced, suggesting that $96 \mathrm{~h}$ fermentation was the best time for oil degradation.

Tables 2 and 3 show the medium-long-chain fatty acids and short-chain fatty acids identified in $P$. aeruginosa M4 degradation products at various time points. The main medium-long-chain fatty acids were $\mathrm{C} 18$ linoleic acid and $\mathrm{C} 16$ palmitic acid. Acetic and n-butyric acids were the main short-chain fatty acids. Vegetable oil contains saturated and unsaturated fats with a mixture of triglycerides, diglycerides, monoglycerides, and free fatty acids. In the process of metabolizing glycerides as carbon sources, they are first broken down by lipase into glycerol and fatty acids. Ramachandran et al. (2007) reported that most fatty acids, including palmitic and linoleic acids, found in vegetable oil are substrates for lipase hydrolysis. It is well known that the formation of acetic acid is through $\beta$-oxidation of long-chain-fatty acids. Butyric acid could be a degradation product of medium-long-chain fatty acids degradation or formed via the polymerization of these acetic acids. This pathway needs further analysis to understand its implications for fermentation.

Acetic acid is used in cell biomass synthesis via the acetyl coenzyme A pathway, which is why we were able to observe very little accumulation of acetic acid during fermentation experiments. However, 
along with the hydrolyzation of the ester bonds by lipase, the total medium-long-chain fatty acid content increased and reached a maximum at $72 \mathrm{~h}$. This shows that the hydrolysis rate is higher than the $\beta$ oxidation rate in fermentations. From $72 \mathrm{~h}$ to $96 \mathrm{~h}$, the concentrations of linoleic and palmitic acid decreased, which implies that the hydrolysis was completed at $72 \mathrm{~h}$ while the $\beta$ oxidation continued up to the experimental end point.

As shown in Fig. 4, the clear medium turned turbid following fermentation, and the soybean oil on the surface of the medium had disappeared. This demonstrated that there was emulsification of the oil apart from degradation described above. It suggested there might be some biosurfactant produced as a byproduct in oil degradation process, which was confirmed in next part of the study.

\section{WCO degradation and rhamnolipid production by $P$. aeruginosa M4}

The oil degradation and biosurfactant production were investigated using WCO as the only substrate (carbon and energy source). The fermentation broth was also shown to be emulsified, which suggests the presence and production of an emulsifying agent. Previous reports have suggested that other $P$. aeruginosa strains can produce biosurfactants belonging to the rhamnolipid family (Sharma et al. 2019). Thus, the biosurfactant analysis focused on this family of emulsifiers. The cell density, lipase activity, rhamnolipid concentration, and $\mathrm{pH}$ from the fermentations are shown in Fig. 5. The highest cell density of 2.61 , the maximum lipase activity of $15.87 \mathrm{U} / \mathrm{mL}$, and the highest rhamnolipid concentration of $1119.87 \mathrm{mg} / \mathrm{L}$ were to be found.

When fermentation was carried out using an initial WCO concentration of $5 \mathrm{~g} / \mathrm{L}$, it was found that the $\mathrm{pH}$ decreased with the accumulation of medium-long-chain fatty acids before $120 \mathrm{~h}$. After $120 \mathrm{~h}$, the pH increased gradually. However, during this period, cell concentration continued to decrease and rhamnolipid concentration continued to increase. Thus, it could be concluded that rhamnolipid was being produced as a secondary metabolite.

\section{Salt tolerance of $P$. aeruginosa M4}

Due to the high salt content in WCO, it is necessary to assess the salt tolerance of the isolated strain. The growth of $P$. aeruginosa M4 in media with varying salt concentration is shown in Table 4 . Here it could grow well up to $70 \mathrm{~g} / \mathrm{L} \mathrm{NaCl}$, while the Pseudomonas selected by Li et al. (2001) could grow at a 
salt concentration of between $10 \mathrm{~g} / \mathrm{L}$ and $50 \mathrm{~g} / \mathrm{L}$. When $\mathrm{NaCl}$ concentration reached between $100 \mathrm{~g} / \mathrm{L}$ and $150 \mathrm{~g} / \mathrm{L}$, the growth of $P$. aeruginosa M4 was significantly inhibited, and the optimal cell density was observed at a salt concentration of $10 \mathrm{~g} / \mathrm{L}$. The ability of $P$. aeruginosa M4 to grow at higher salt concentration up to $70 \mathrm{~g} / \mathrm{L}$ suggests that it may be an ideal candidate for applications using high salt of WCO as the primary carbon source.

\section{Discussion}

Most households in China like to use a large amount of edible oil for cooking dishes, so the output of WCO is huge (Demichelis et al. 2017). At present, there is no effective way for WCO treatment and utilization, which results in various environmental and social problems (Zhang et al. 2010). Funston et al. (2016) and Pacheco et al. (2012) studied the rhamnolipid production using glycerol as a substrate, and Müller et al. (2010) reported the rhamnolipid production with sunflower oil. However, there were few reports on the rhamnolipid production from WCO. The rhamnolipid production from WCO is expected to be a win-win method for both effectively treating WCO and economically producing biosurfactants. The P. aeruginosa M4 isolated in this study had a rhamnolipid production capacity up to $1119.87 \mathrm{mg} / \mathrm{L}$, which was much higher than the reported rhamnolipid concentrations of 430 and $299 \mathrm{mg} / \mathrm{L}$ produced by P. aeruginosa (Radzuan et al. 2017; Ramírez et al. 2016). Moreover, it could tolerate a high concentration of salt, which usually was contained in WCO. This suggested that P. aeruginosa M4 may be a good candidate for both WCO treatment and biosurfactants production.

Various types of carbon sources including glucose, fructose, malt extract powder, and soluble starch were usually used as the substrate for lipase production (Zamroni 2009). However, the carbon catabolic regulation in microbial systems preferentially catabolizes the best carbon source, the one which facilitates cell growth being used before any of the others (Saxena et al. 2003). It is well known that organic nitrogen sources can affect enzyme synthesis because they provide the amino acids and other growth factors required for cell metabolism and protein synthesis (Iftikhar et al. 2011). This study showed that oil and tryptone was the best carbon and nitrogen source to maximize the bacteria growth and lipase activity. Low inoculation ratios could prolong the lag phase of cell growth, while high inoculation ratios might lead to restrictions in nutrient and oxygen availability. The optimum inoculum ratio of $5 \%(\mathrm{v} / \mathrm{v})$ was obtained in this study. Temperature affects the secretion of extracellular enzymes. The temperature of 
$35^{\circ} \mathrm{C}$ achieved the maximum lipase activity $(19.87 \mathrm{U} / \mathrm{mL})$, which was consistent with the result reported by Prasad (2014). The pH of the environment greatly affects cell growth and lipase activity. Usually, the acidic $\mathrm{pH}$ is most suitable for enzyme production (Hiol et al. 2000). Diaz et al. (2006) reported that the optimal pH was 6.5 for lipase production by Rhizopus homothallicus, while it was 8.0 in this study. This may be because that the higher initial $\mathrm{pH}$ could enable the fermentative system to tolerate higher concentrations of fatty acids.

Combined with previous study, the formation pathway of rhamnolipid was illustrated in Fig. 6. Abdel-Mawgoud et al. (2011) and Gutiérrez-Gómez et al. (2019) described the metabolic pathway of rhamnolipid biosynthesis from glucose, where both R-3-hydroxyalkanoate and the rhamnose precursor were synthesized from glucose. In this study, the only carbon source for rhamnolipid production was WCO. In case of WCO, the rhamnose precursor could be synthesized from glycerol, which was a hydrolysis product of WCO. Theoretically, the C10 medium-long chain fatty acids of oil degradation products might be directly used as R-3-hydroxyalkanoate precursor. However, Abdel-Mawgoud et al. (2014) pointed out that, R-3-hydroxyalkanoate precursor was synthesized de novo from acetyl-CoA, even with fatty acids as a carbon source. The C10 medium-long chain fatty acids could not be directly transformed to the R-3-hydroxyalkanoate precursor.

Author contributions JS, XFL and DL conceived and designed the research. JS and YCC performed the experiments. JS, YR and DL analyzed the date. JS and DL wrote the manuscript. All authors read and approved the manuscript.

Funding information This research was jointly supported by the Science and technology program of Sichuan Province (20ZHSF0170), the CAS "Light of West China" (2018XBZG_XBQNXZ_A_004, 2019XBZG_JCTD_ZDSYS_001), the Youth Innovation Promotion Association of the CAS (2017423), and the Special fund for talented persons of Sichuan provincial Party Committee Organization Department.

\section{Compliance with ethical standards}

Conflict of interest The authors declare that they have no conflict of interest.

Ethical approval This paper does not contain any studies with human participants or animals. 


\section{References}

Awasthi MK, Selvam A, Chan MT, Wong JW (2018) Bio-degradation of oily food waste employing thermophilic bacterial strains. Bioresour Technol 248: 141-147. https://doi.org/10.1016/j.biortech.2017.06.115

Abdel-Mawgoud AM, Hausmann R, Lépine F, Müller MM, Déziel E (2011) Rhamnolipids: Detection, Analysis, Biosynthesis, Genetic Regulation, and Bioengineering of Production. Springer-Verlag, Berlin Heidelberg, Berlin, Heidelberg 13-55. https://xs.scihub.ltd/https://doi.org/10.1007/978-3642-14490-5 2

Abdel-Mawgoud AM, Lépine F, Déziel E (2014) A stereospecific pathway diverts $\beta$-Oxidation intermediates to the biosynthesis of rhamnolipid biosurfactants. Chem Biol 21(1): 156-164. https://doi.org/10.1016/j.chembiol.2013.11.010

Benincasa M, Contiero J, Manresa MA, Moraes IO (2002) Rhamnolipid production by Pseudomonas aeruginosa LBI growing on soapstock as the sole carbon source. J Food Eng 54(4): 283-288. https://doi.org/10.1016/S0260-8774(01)00214-X

Chan MT, Selvam A, Wong JWC (2016) Reducing nitrogen loss and salinity during 'struvite' food waste composting by zeolite amendment. Bioresour Technol 200: 838-844. https://doi.org/10.1016/j.biortech.2015.10.093

Chen Y, Xiao B, Chang J, Fu Y, Lv P, Wang X (2009) Synthesis of biodiesel from waste cooking oil using immobilized lipase in fixed bed reactor. Energ Conv Manage 50:668-673. https://doi.org/10.1016/j.enconman.2008.10.011

Cammarota MC, Freire DMG (2006) A review on hydrolytic enzymes in the treatment of wastewater with high oil and grease content. Bioresour Technol 97(17): 2195-2210. https://doi.org/10.1016/j.biortech.2006.02.030

Demichelis F, Pleissner D, Fiore S, Mariano S, Gutiérrez IMN, Schneider R, Venus J (2017) Investigation of food waste valorization through sequential lactic acid fermentative production and anaerobic digestion of fermentation residues. Bioresour Technol 241: 508-516. https://doi.org/10.1016/j.biortech.2017.05.174

Dobler L, Vilela LF, Almeida RV, Neves BC (2016) Rhamnolipids in perspective: gene regulatory pathways, metabolic engineering, production and technological forecasting. New Biotechnol 33: 123-135. https://xs.scihub.ltd/https://doi.org/10.1016/j.nbt.2015.09.005

Dastager SG, Deepa CK, Puneet SC, Nautiyal CS, Pandey A (2009) Isolation and characterization of plant growth-promoting strain Pantoea NII-186. From Western Ghat Forest soil, India. Lett Appl Microbiol 49 (1): 20-25. https://doi.org/10.1111/j.1472-765X.2009.02616.x

Diaz JCM, Rodriguez JA, Roussos S, Cordova J, Abousalham A, Carriere F, Baratti J (2006) Lipase from the thermotolerant fungus Rhizopus homothallicus is more thermostable when produced using solid state fermentation than liquid fermentation procedures. Enzyme Microbial Technol 39(5):10421050. https://doi.org/10.1016/j.enzmictec.2006.02.005

Feng L, Guo MY, Cui JY (2017) Optimization of cultural conditions for plant oil-degrading strain and isolation of plant oil-degradation bacterial in sludge. J Qingdao Univ Technol 2017(01):92-99. 10.3969/j.issn.1673 - 4602.2017.01.015

Funston SJ, Tsaousi K, Rudden M, Smyth TJ, Stevenson PS, Marchant R, Banat IM (2016) Characterising rhamnolipid production in Burkholderia thailandensis E264, a non-pathogenic 
producer. Appl Microbiol Biotechnol 100(18):

7945-7956.

https://xs.scihub.ltd/https://doi.org/10.1007/s00253-016-7564-y

Gudina EJ, Pereira JF, Costa R, Coutinho JA, Teixeira JA, Rodrigues LR (2013) Biosurfactant-producing and oil-degrading Bacillus subtilis strains enhance oil recovery in laboratory sand-pack columns. J Hazard Mater 261:106-113. https://doi.org/10.1016/j.jhazmat.2013.06.071

Gupta N, Sahai V, Gupta R (2007) Alkaline lipase from a novel strain Burkholderia multivorans: Statistical medium optimization and production in a bioreactor. Process Biochem 42(4):518-526. https://xs.scihub.1td/https://doi.org/10.1016/j.procbio.2006.10.006

Gutiérrez-Gómez U, Servín-González L, Soberón-Chávez G (2019) Role of $\beta$-oxidation and de novo fatty acid synthesis in the production of rhamnolipids and polyhydroxyalkanoates by Pseudomonas aeruginosa. Appl microbiol biotechnol 103(9): 3753-3760. https://doi.org/10.1007/s00253-01909734-X

HKEPD (2015) Monitoring of Solid Waste in Hong Kong - Waste Statistics for 2015. Environment Protection Department, Hong Kong SAR

Hiol A, Jonzo M, Rugani N, Druet D, Sarda L, Comeau L (2000) Purification and characterization of an extracellular lipase from a thermophilic Rhizopus oryzae strain isolated from palm fruit. Enzyme Microbial Technol 26(5-6):421-430. https://doi.org/10.1016/S0141-0229(99)00173-8

Iftikhar T, Niaz M, Jabeen R, Haq IU (2011) Purification and characterization of extracellular lipases. Pak J Bot 43(3):1541-1545

Kiran EU, Trzcinski AP, Liu Y (2015) Enhancing the hydrolysis and methane production potential of mixed food waste by an effective enzymatic pretreatment. Bioresour Technol 183:47-52. https://doi.org/10.1016/j.biortech.2015.02.033

Kantak JB, Bagade AV, Mahajan SA, Pawar SP, Shouche YS, Prabhune AA (2011) Isolation, identification and optimization of a new extracellular lipase producing strain of Rhizopus sp. Appl Biochem Biotechnol 164(7): 969-978. https://doi.org/10.1007/s12010-011-9188-0

Lan G, Fan Q, Liu Y, Chen C, Li G, Liu Y, Yin X (2015) Rhamnolipid production from waste cooking oil using Pseudomonas SWP-4. J Biochem Eng 101:44-54. https://doi.org/10.1016/j.bej.2015.05.001

Li EY, Cheng JH, Shi LW (2001) Study on Facultative Halophiles. J Changzhou Univ 13(4):4-6. 10.3969/j.issn.2095-0411.2001.04.002

Maddikeri GL, Gogate PR, Pandit AB (2015) Improved synthesis of sophorolipids from waste cooking oil using fed batch approach in the presence of ultrasound. J Chem Eng 263:479-487. https://xs.scihub.ltd/https://doi.org/10.1016/j.cej.2014.11.010

Mobarak-Qamsari E, Kasra KR, Moosavi NZ (2011) Isolation and identification of a novel, lipaseproducing bacterium, Pseudomnas aeruginosa KM110. Iran J Microbiol 3(2): 92

Müller MM, Hörmann B, Syldatk C, Hausmann R (2010) Pseudomonas aeruginosa PAO1 as a model for rhamnolipid production in bioreactor systems. Appl Microbiol Biotechnol 87(1):167-174. https://xs.scihub.ltd/https://doi.org/10.1007/s00253-010-2513-7

Pleissner D, Lam WC, Sun Z, Ki Lin CS (2013) Food waste as nutrient source in heterotrophic microalgae $\quad$ cultivation. $\quad$ Bioresour $\quad$ Technol 137: 139-146. https://doi.org/10.1016/j.biortech.2013.03.088

Patil PD, Gude VG, Reddy HK, Muppaneni T, Deng S (2012) Biodiesel production from waste cooking oil using sulfuric acid and microwave irradiation processes. J Environ Prot (Irvine, Calif) 3:107. http://dx.doi.org/10.4236/jep.2012.31013 
Pleissner D, Demichelis F, Mariano S, Fiore S, Navarro Gutiéerrez I, Scheneider R, Venus J (2017) Direct production of lactic acid based on simultaneous saccharification and fermentation of mixed restaurant food waste. J Clean Prod 143:615-623. https://doi.org/10.1016/j.jclepro.2016.12.065

Pansiripat S, Pornsunthorntawee O, Rujiravanit R, Kitiyanan B, Somboonthanate P, Chavadej S (2010) Biosurfactant production by Pseudomonas aeruginosa SP4 using sequencing batch reactors: effect of oil-to-glucose ratio. J Biochem Eng 49:185-191. https://doi.org/10.1016/j.bej.2009.12.011

Pacheco GJ, Reis RS, Fernandes ACLB, da Rocha SLG, Pereira MD, Perales J, Freire DMG (2012) Rhamnolipid production: effect of oxidative stress on virulence factors and proteome of Pseudomonas aeruginosa PA1. Appl Microbiol Biotechnol 95(6):1519-1529. https://xs.scihub.ltd/https://doi.org/10.1007/s00253-012-4258-y

Prasad MP (2014) Production of lipase enzyme from Pseudomonas aeruginosa isolated from lipid rich soil. Int J Pure Appl Biosci 2:77-81

Rabiei A, Sharifinik M, Niazi A, Hashemi A, Ayatollahi S (2013) Core flooding tests to investigate the effects of IFT reduction and wettability alteration on oil recovery during MEOR process in an Iranian oil reservoir. Appl Microbiol Biotechnol 97 (13): 5979-5991. https://xs.scihub.ltd/https://doi.org/10.1007/s00253-013-4863-4

Reddy KS, Khan MY, Archana K, Reddy, MG, Hameeda B (2016) Utilization of mango kernel oil for the rhamnolipid production by Pseudomonas aeruginosa DR1 towards its application as biocontrol agent. Bioresour Technol 221: 291-299. https://doi.org/10.1016/j.biortech.2016.09.041

Ramachandran S, Singh SK, Larroche C, Soccol CR, Pandey A (2007) Oil cakes and their biotechnological applications-A review. Bioresour Technol 98(10): 2000-2009. https://xs.scihub.ltd/https://doi.org/10.1016/j.biortech.2006.08.002

Radzuan MN, Banat IM, Winterburn J (2017) Production and characterization of rhamnolipid using palm oil agricultural refinery waste. Bioresour Technol 225: 99-105. https://doi.org/10.1016/j.biortech.2016.11.052

Ramírez IM, Vaz DA, Banat IM, Marchant R, Alameda EJ, Román MG (2016) Hydrolysis of olive mill waste to enhance rhamnolipids and surfactin production. Bioresour Technol 205: 1-6. https://doi.org/10.1016/j.biortech.2016.01.016

Sharma S, Datta P, Kumar B, Tiwari P, Pandey LM (2019) Production of novel rhamnolipids via biodegradation of waste cooking oil using Pseudomonas aeruginosa MTCC7815. Biodegrada 30(4): 301-312. https://xs.scihub.ltd/https://doi.org/10.1007/s10532-019-09874-x

Sharma D, Sharma B, Shukla AK (2011) Biotechnological approach of microbial lipase: a review. Biotechnol 10(1): 23-40. http://dx.doi.org/10.3923/biotech.2011.23.40

Saxena RK, Sheoran A, Giri B, Davidson WS (2003) Purification strategies for microbial lipases. J Microbiol Method 52(1): 1-18. https://doi.org/10.1016/S0167-7012(02)00161-6

Thavasi R, Jayalakshmi S, Balasubramanian T, Banat IM (2007) Biosurfactant production by Corynebacterium kutscheri from waste motor lubricant oil and peanut oil cake. Lett Appl Microbiol 45(686-69):1. https://doi.org/10.1111/j.1472-765X.2007.02256.X

Taylor KB (2002) Enzyme kinetics and mechanisms. Springer Sci \& Business Media.

Wang X, Selvam A, Chan MT, Wong JWC (2013) Nitrogen conservation and acidity control during food wastes composting through struvite formation. Bioresour Technol 147: 17-22. https://doi.org/10.1016/j.biortech.2013.07.060

Zhang Z, Gai L, Hou Z, Yang C, Ma C, Wang Z, Sun B, He X, Tang H, Xu P (2010) Characterization and biotechnological potential of petroleum-degrading bacteria isolated from oil-contaminated soils. 
Bioresour Technol 101:8452- 8456. https://doi.org/10.1016/j.biortech.2010.05.060

Zhang X, Xu D, Zhu C, Lundaa T, Scherr KE (2012) Isolation and identification of biosurfactant producing and crude oil degrading Pseudomonas aeruginosa strains. J Chem Eng 209: 138-146. https://doi.org/10.1016/j.cej.2012.07.110

Zhu L, Yang X, Xue C, Chen Y, Qu L, Lu W (2012) Enhanced rhamnolipids production by Pseudomonas aeruginosa based on a pH stage-controlled fed-batch fermentation process. Bioresour Technol 117: 208-213. https://doi.org/10.1016/j.biortech.2012.04.091

Zamroni A (2009) Isolation and Characterization of Lipase-Producing Bacteria from Palm Oil Contaminated Wastes and Its Application for Methyl Ester Synthesis. Prince Songkla Univ 


\section{Figure captions}

Fig. 1 a Morphology of $P$. aeruginosa M4 shown by SEM. b Phylogenetic tree of P. aeruginosa M4 constructed by Neighbor-Joining algorithim.

Fig. 2 Change in cell density and lipase activity at various a carbon sources, $\mathbf{b}$ nitrogen sources, various c inoculum ratio, $\mathbf{d}$ temperature and $\mathbf{e} \mathrm{pH}$.

Fig. 3 Oil degradation characteristics of $P$. aeruginosa M4 under optimal conditions.

Fig. 4 Photograph of degradation by P. aeruginosa M4 with soybean oil as the only carbon source.

Fig. 5 Time course profiles of a cell density, b lipase activity, $\mathbf{c}$ rhamnolipid concentration, and $\mathbf{d} \mathrm{pH}$ by P. aeruginosa M4 degraded different concentrations WCO.

Fig. 6 Proposed synthetic pathway of rhamnolipid using WCO as sole carbon source. 


\section{Table 1}

Oil degradation characteristics of the five screened strains

\begin{tabular}{llllll}
\hline Strain number & M4 & M8 & M9 & M12 & M14 \\
\hline Cell density (OD 600$)$ & $2.81 \pm 0.13$ & $2.12 \pm 0.02$ & $2.67 \pm 0.08$ & $2.51 \pm 0.02$ & $2.11 \pm 0.06$ \\
Lipase activity (U/mL) & $7.03 \pm 0.02$ & $1.56 \pm 0.02$ & $1.41 \pm 004$ & $0.65 \pm 0.01$ & $1.06 \pm 001$ \\
Oil degradation rate (\%) & $93.49 \pm 0.12$ & $58.95 \pm 0.89$ & $52.61 \pm 0.76$ & $43.22 \pm 0.10$ & $37.15 \pm 0.34$ \\
\hline
\end{tabular}


Table 2

The content of medium-long chain fatty acids in the degradation products

\begin{tabular}{|c|c|c|c|c|c|c|}
\hline Fatty $\operatorname{acid}(\mu \mathrm{g} / \mathrm{mL})$ & $12 \mathrm{~h}$ & $24 h$ & $36 h$ & $48 h$ & $72 \mathrm{~h}$ & $96 h$ \\
\hline hexanoic acid(C6) & 0.29 & 0.28 & 0.18 & 0.20 & 0.21 & 0.26 \\
\hline octanoic $\operatorname{acid}(\mathrm{C} 8)$ & 0.17 & 0.69 & 3.15 & 13.71 & 7.75 & 6.96 \\
\hline decanoic $\operatorname{acid}(\mathrm{C} 10)$ & 0.12 & 0.76 & 1.58 & 3.08 & 2.16 & 1.72 \\
\hline undecanoic $\operatorname{acid}(\mathrm{C} 11)$ & 0.10 & 0.70 & 0.52 & 0.66 & 10.92 & 0.69 \\
\hline Lauric acid(C12) & 0.51 & 2.67 & 3.64 & 9.64 & 8.36 & 14.91 \\
\hline tridecanoic acid(C13) & 0.65 & 1.22 & 0.80 & 1.27 & 1.60 & 1.05 \\
\hline Myristic acid(C14) & 2.90 & 4.21 & 4.49 & 6.96 & 9.75 & 7.32 \\
\hline pentadecanoic acid(C15) & 3.90 & 1.37 & 1.68 & 2.91 & 2.94 & 3.02 \\
\hline Palmitic acid(C16) & 36.96 & 109.85 & 143.71 & 336.23 & 600.28 & 508.61 \\
\hline heptadecanoic acid(C17) & 16.69 & 25.69 & 7.60 & 12.44 & 17.63 & 12.43 \\
\hline linoleic acid(C18) & 78.05 & 526.99 & 789.04 & 2118.99 & 5028.33 & 3637.10 \\
\hline arachidic acid(C20) & 7.32 & 12.15 & 41.43 & 133.39 & 217.77 & 149.44 \\
\hline Henecanoic $\operatorname{acid}(\mathrm{C} 21)$ & 16.10 & 1.66 & 2.33 & 5.47 & 6.10 & 5.73 \\
\hline behenic $\operatorname{acid}(\mathrm{C22})$ & 43.77 & 18.55 & 39.44 & 74.93 & 102.49 & 92.55 \\
\hline tricosanoic acid(C23) & 2.42 & 1.24 & 1.90 & 5.75 & 5.89 & 3.86 \\
\hline lignoceric $\operatorname{acid}(\mathbf{C} 24)$ & 29.90 & 6.75 & 6.10 & 21.80 & 21.03 & 17.96 \\
\hline Total & 239.87 & 714.77 & 1047.61 & 2747.43 & 6043.22 & 4463.61 \\
\hline
\end{tabular}




\section{Table 3}

The contents of short chain fatty acids in the degradation products

\begin{tabular}{lllllll}
\hline Fatty acid $(\boldsymbol{\mu g} / \mathbf{m L})$ & $\mathbf{1 2 h}$ & $\mathbf{2 4 h}$ & $\mathbf{3 6 h}$ & $\mathbf{4 8 h}$ & $\mathbf{7 2 h}$ & $\mathbf{9 6 h}$ \\
\hline Acetic Acid & 38.77 & 36.84 & 25.13 & 16.22 & 18.93 & 15.64 \\
Propanoic Acid & 1.64 & 0.99 & 0.04 & 0.17 & 2.00 & 0.55 \\
Isobutyric acid & 0.42 & 0.91 & 0.87 & 1.19 & 0.78 & 0.82 \\
n-Butyric acid & 13.45 & 1.66 & 7.87 & 13.30 & 40.43 & 11.22 \\
Isovaleric acid & 2.71 & 0.30 & 0.87 & 1.94 & 1.14 & 0.84 \\
valeric acid & 0.37 & 0.20 & 0.11 & 0.16 & 0.22 & 0.14 \\
Total & & & & & & \\
\hline
\end{tabular}


bioRxiv preprint doi: https://doi.org/10.1101/2020.03.09.983478; this version posted March 19, 2020. The copyright holder for this preprint (which was not certified by peer review) is the author/funder, who has granted bioRxiv a license to display the preprint in perpetuity. It is made available under aCC-BY-NC-ND 4.0 International license.

Table 4

Salt tolerance of P. aeruginosa M4

\begin{tabular}{lllllll}
\hline Salt concentration(g/L) & $\mathbf{0}$ & $\mathbf{2}$ & $\mathbf{5}$ & $\mathbf{1 0}$ & $\mathbf{1 5}$ & $\mathbf{2 0}$ \\
\hline Cell density & $1.33 \pm 0.05$ & $1.37 \pm 0.05$ & $1.47 \pm 0.02$ & $1.49 \pm 0.01$ & $1.44 \pm 0.01$ & $1.36 \pm 0.13$ \\
\hline Salt concentration(g/L) & $\mathbf{2 5}$ & $\mathbf{3 0}$ & $\mathbf{5 0}$ & $\mathbf{7 0}$ & $\mathbf{1 0 0}$ & $\mathbf{1 5 0}$ \\
\hline Cell density & $1.32 \pm 0.06$ & $1.24 \pm 0.04$ & $1.13 \pm 0.02$ & $0.78 \pm 0.02$ & $0.04 \pm 0.01$ & $0.03 \pm 0.01$ \\
\hline
\end{tabular}


bioRxiv preprint doi: https://doi.org/10.1101/2020.03 09 983478; this version posted March 19, 2020. The copyright holder for this preprint (which was not certified by peer review) is the author/funder, who has granted bioRxiv a license to display the preprint in perpetuity. It is made available under aCC-BY-NC-ND 4.0 International license.

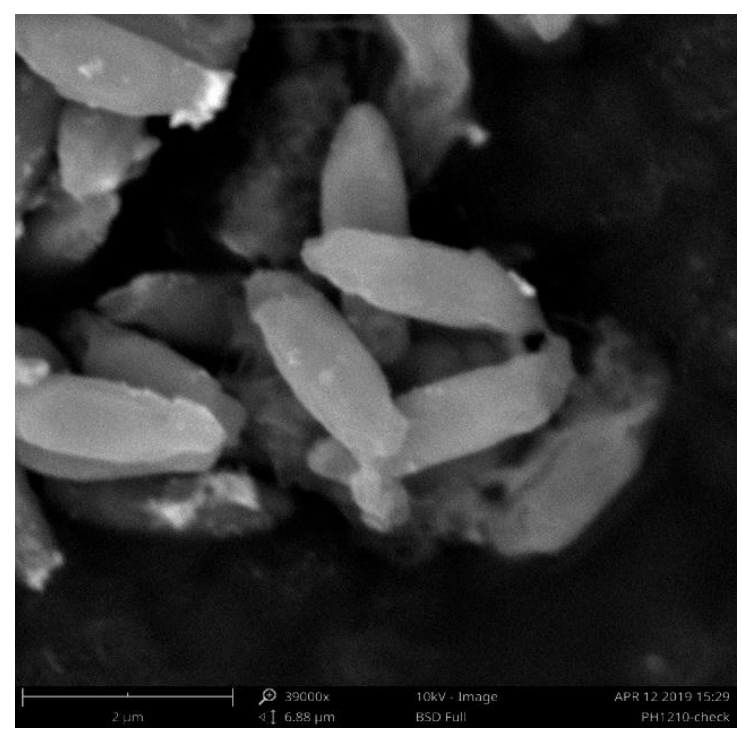

a

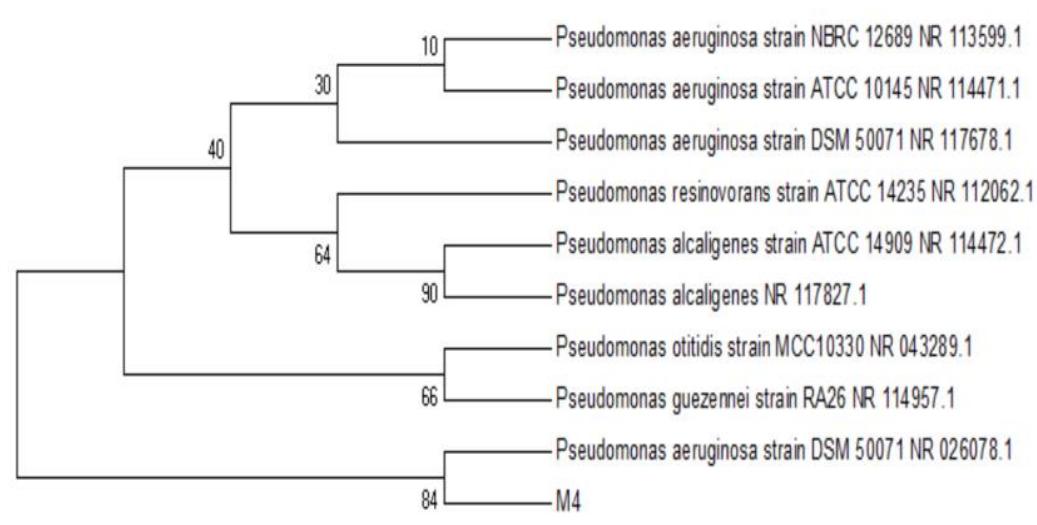

0.1

Fig. 1 


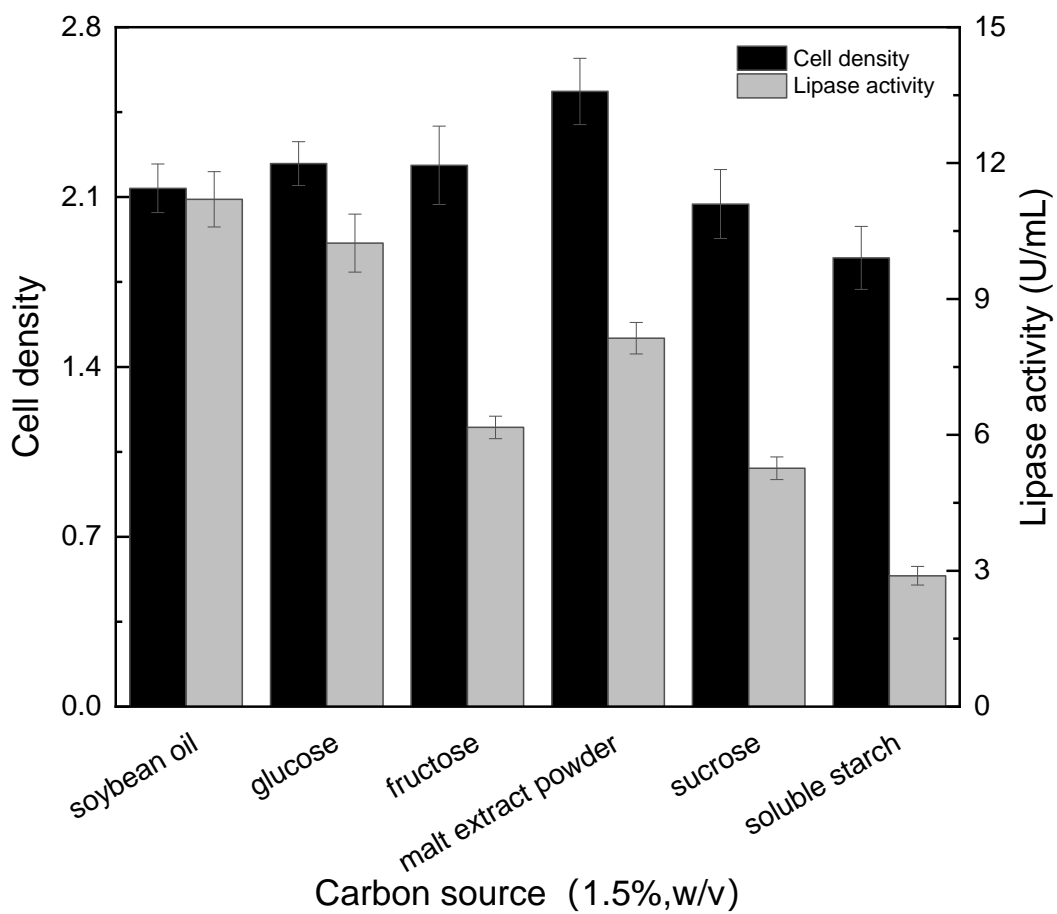

a

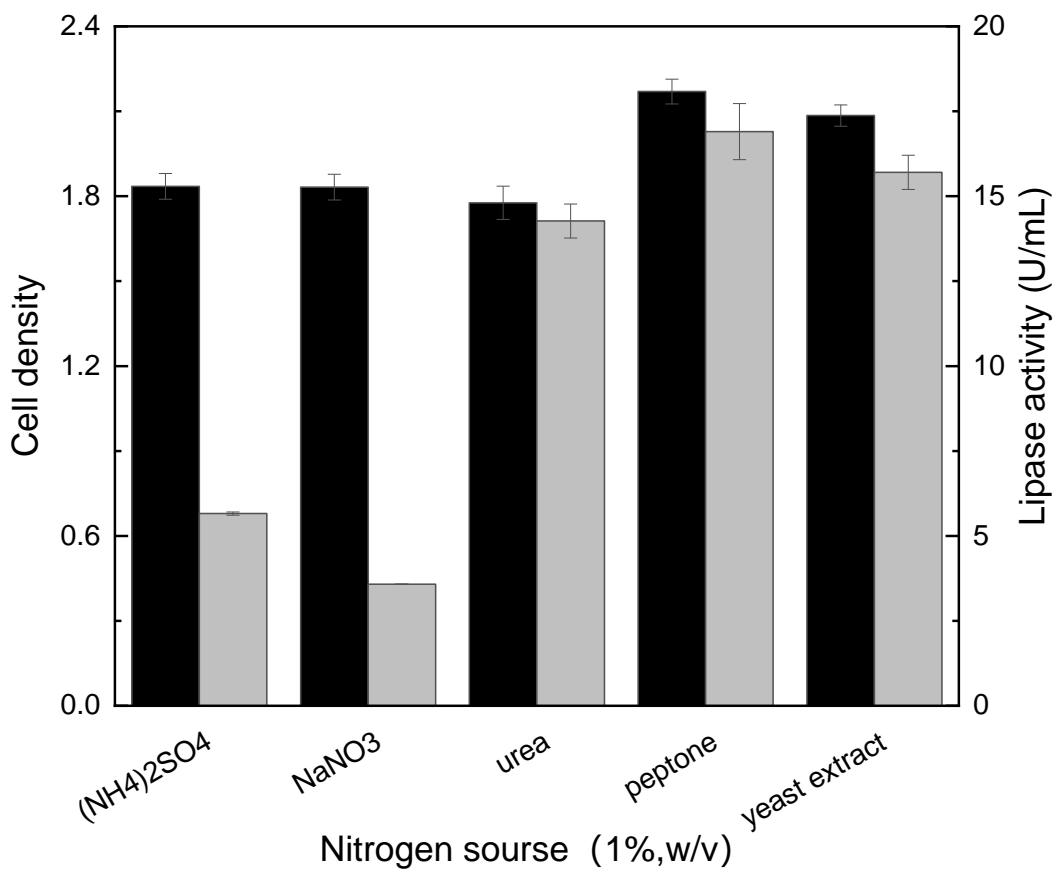




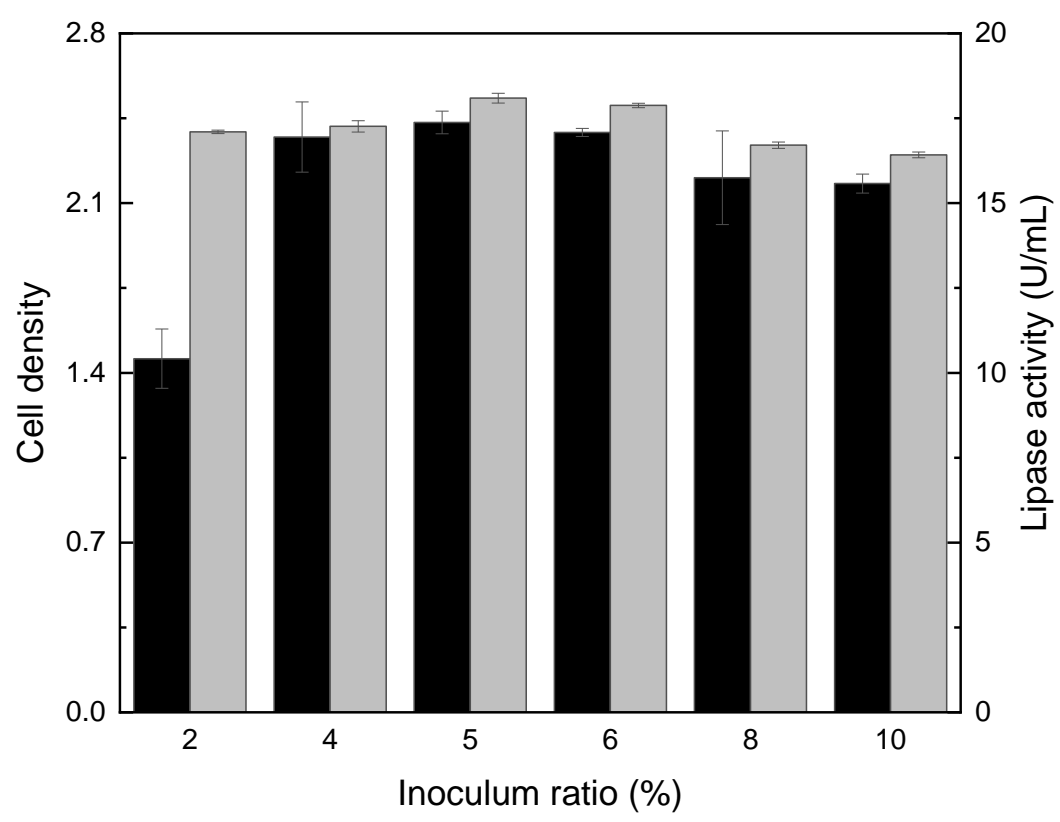

c

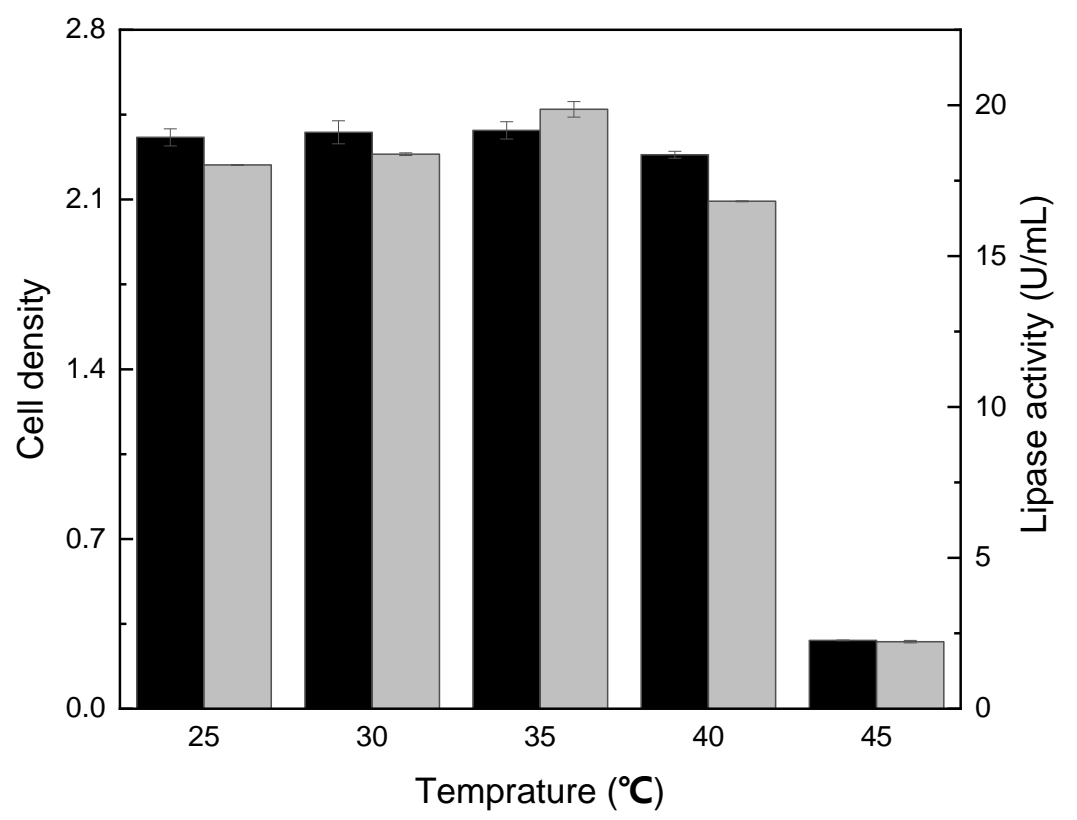

d 
bioRxiv preprint doi: https://doi.org/10.1101/2020.03.09.983478; this version posted March 19, 2020. The copyright holder for this preprint (which was not certified by peer review) is the author/funder, who has granted bioRxiv a license to display the preprint in perpetuity. It is made available under aCC-BY-NC-ND 4.0 International license.

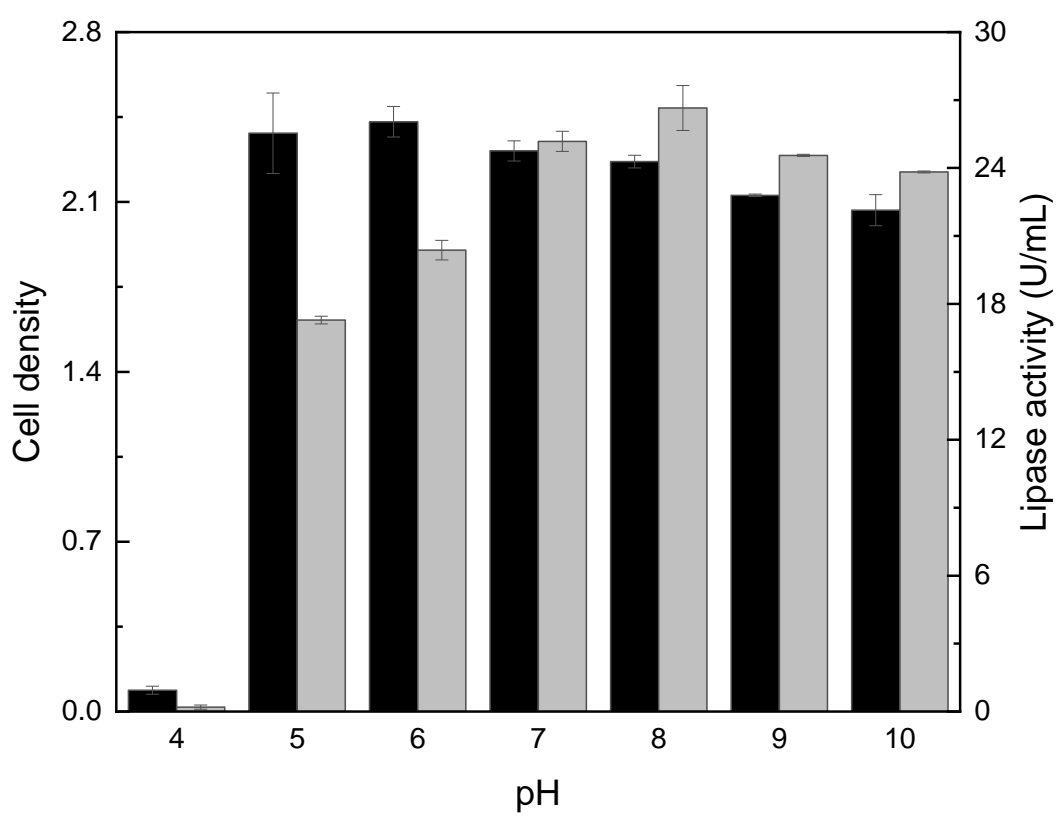

e

Fig. 2 
bioRxiv preprint doi: https://doi.org/10.1101/2020.03 09.983478; this version posted March 19, 2020. The copyright holder for this preprint (which was not certified by peer review) is the author/funder, who has granted bioRxiv a license to display the preprint in perpetuity. It is made available under aCC-BY-NC-ND 4.0 International license.

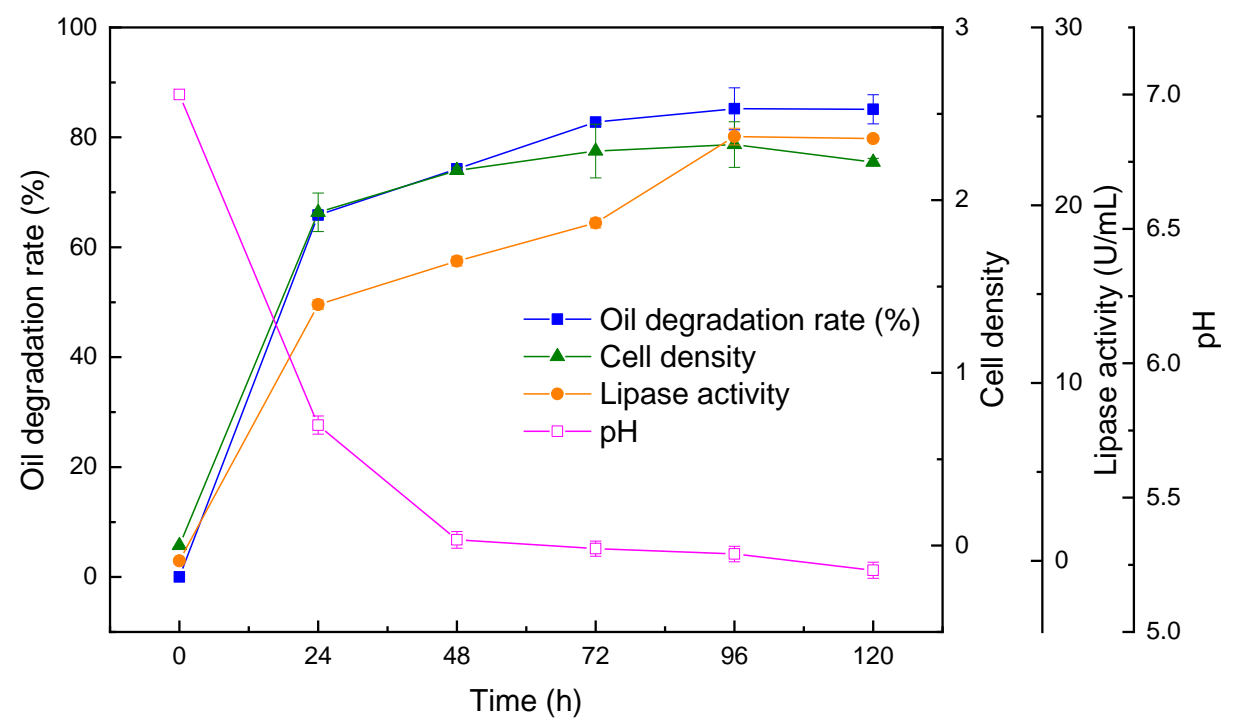

Fig. 3 
bioRxiv preprint doi: https://doi.org/10.1101/2020.03.09.983478; this version posted March 19,2020. The copyright holder for this preprint (which was not certified by peer review) is the author/funder, who has granted bioRxiv a license to display the preprint in perpetuity. It is made available under aCC-BY-NC-ND 4.0 International license.

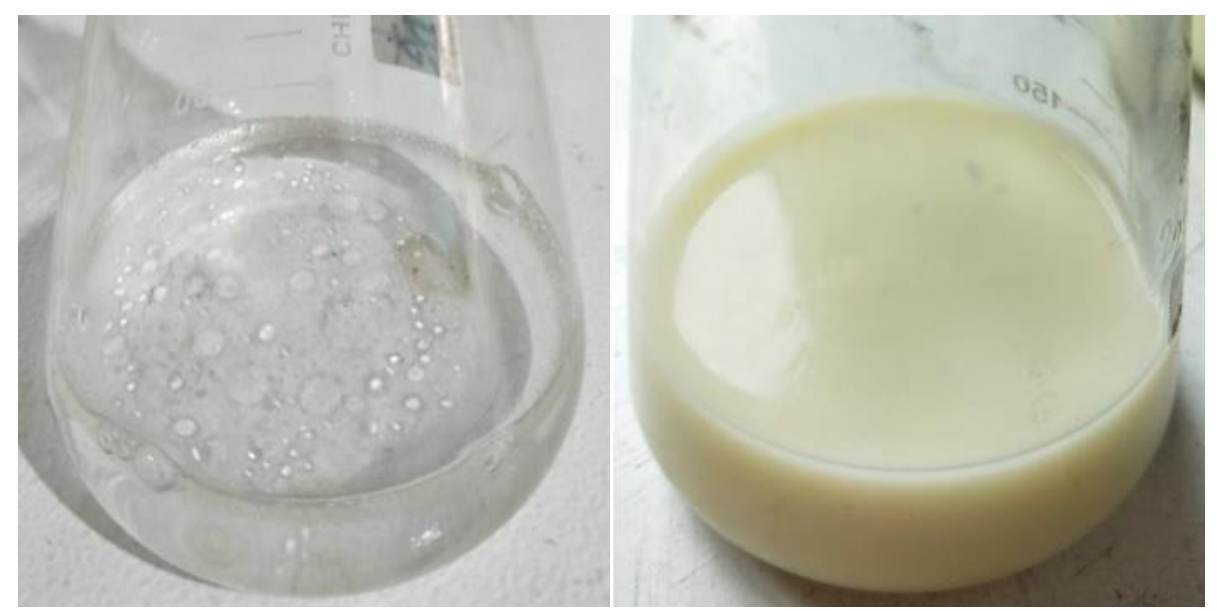

Fig. 4 


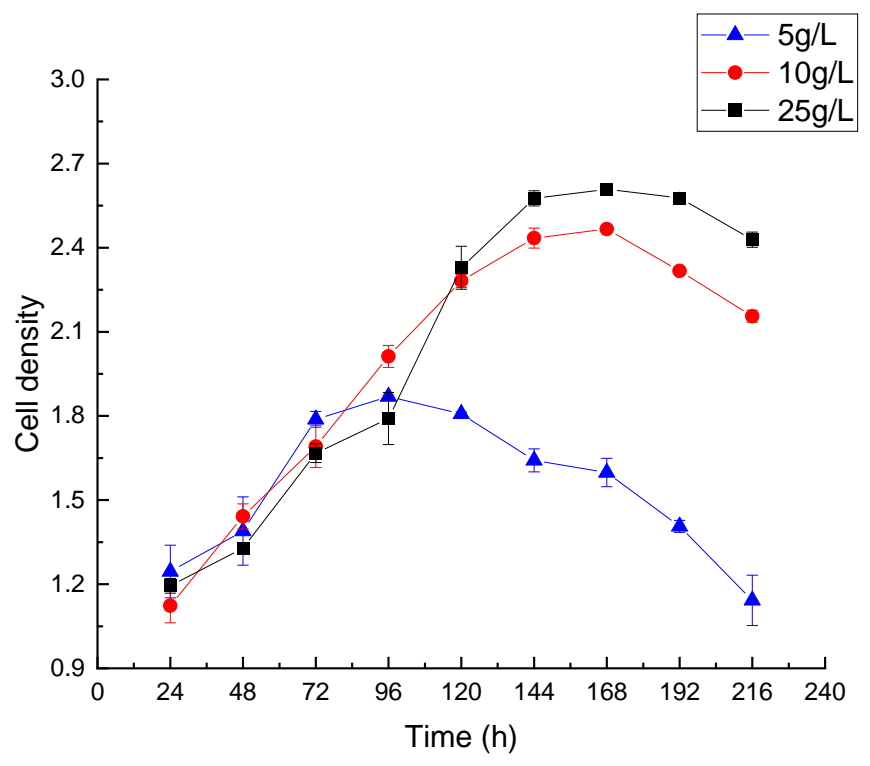

a

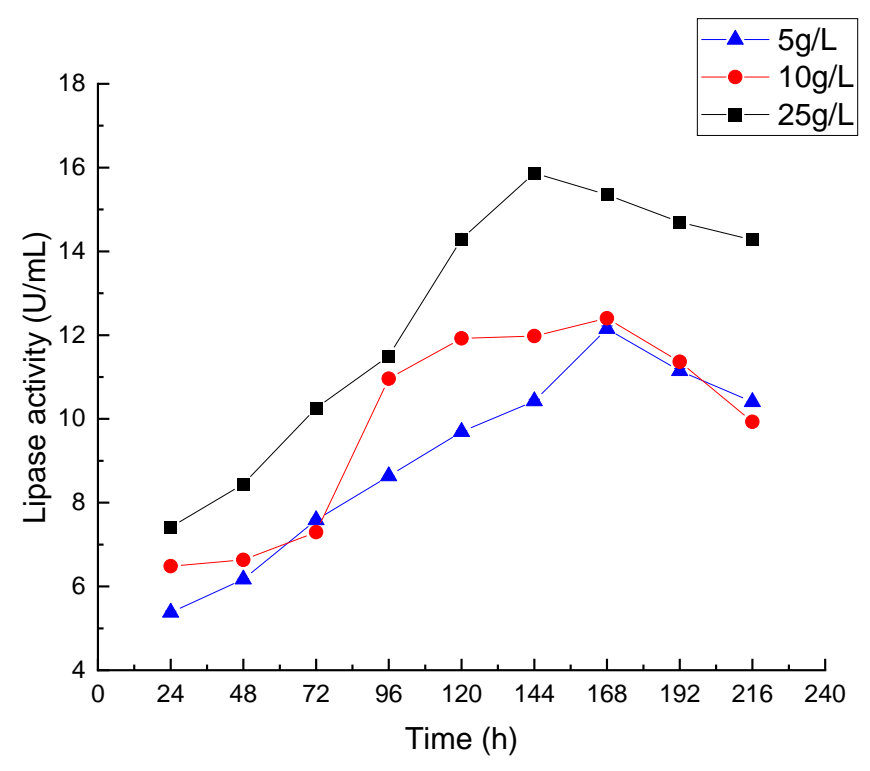




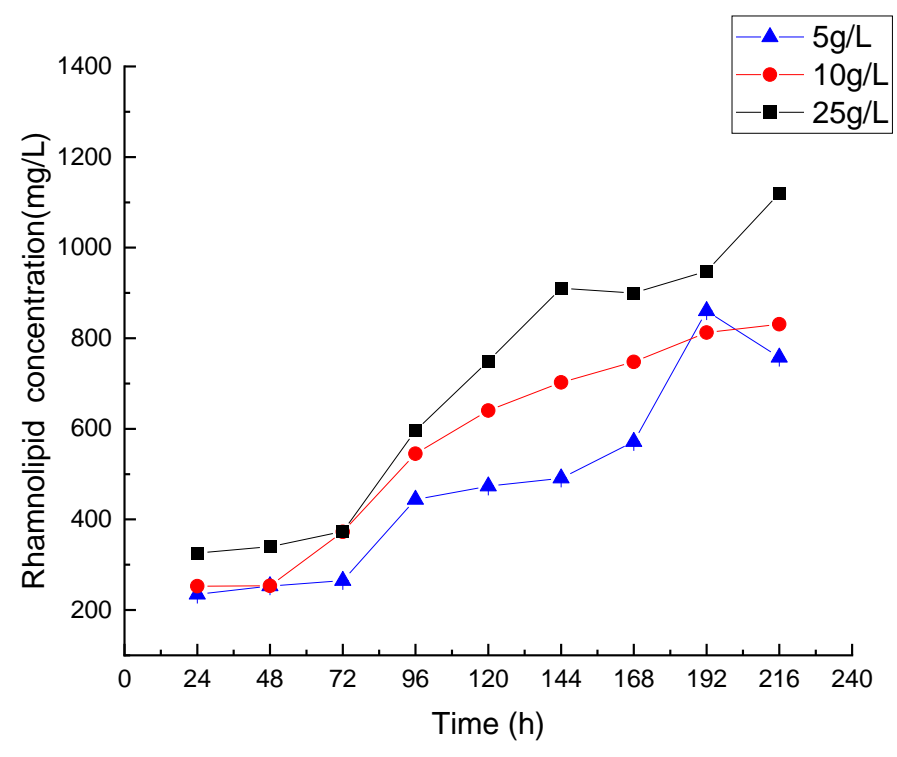

c

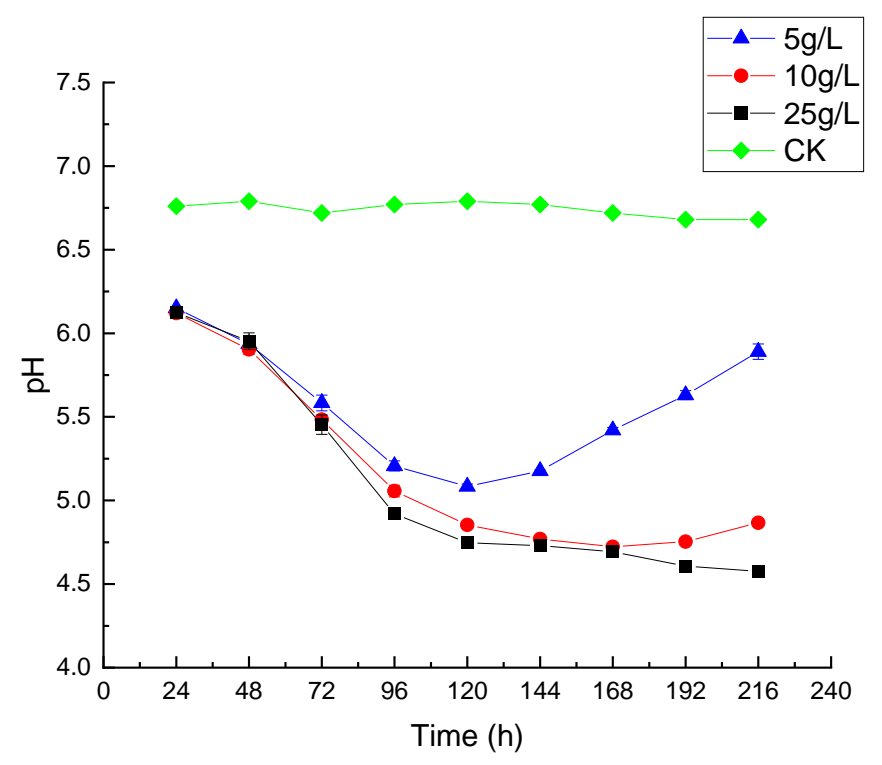

d

Fig. 5 


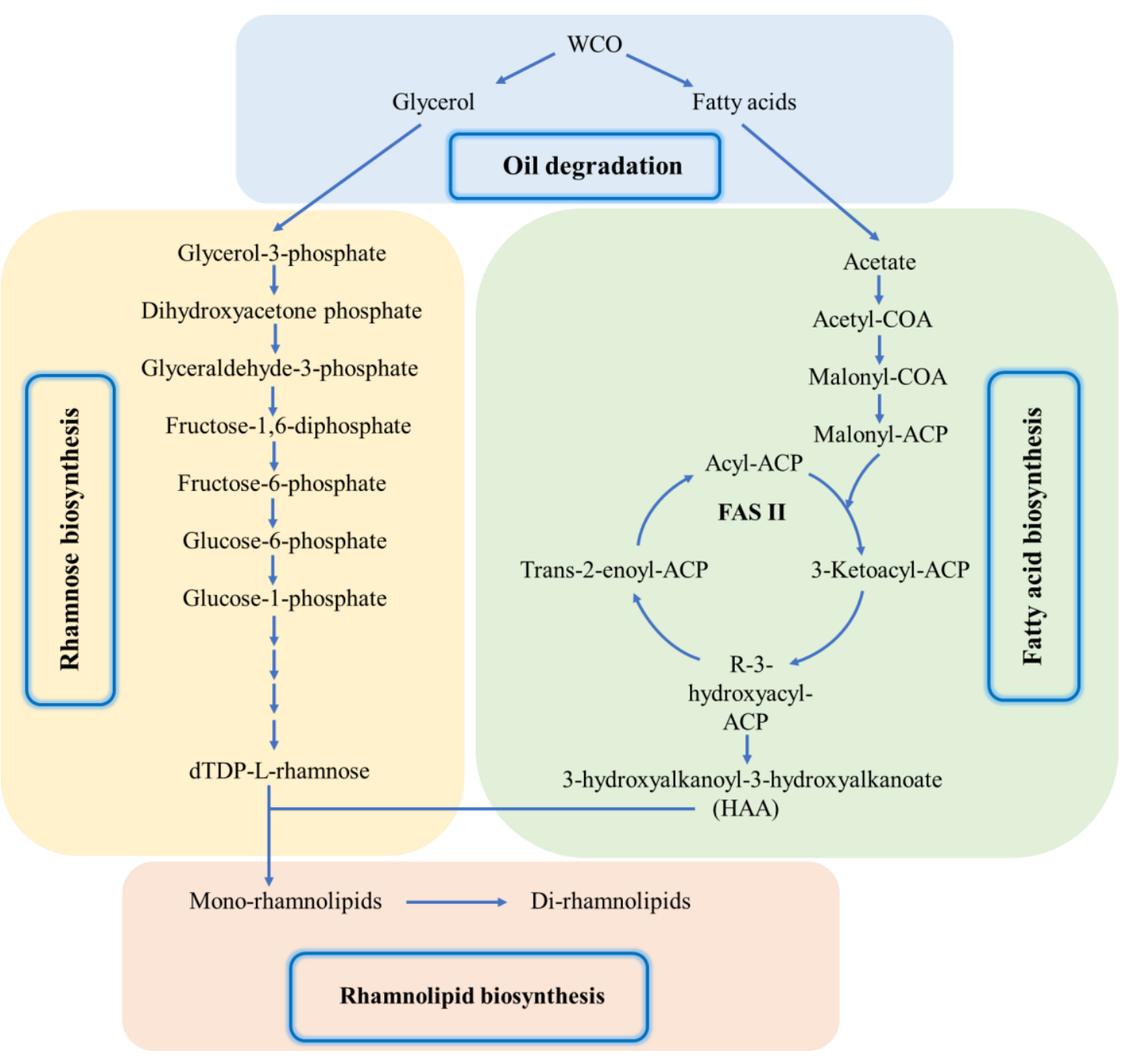

Fig. 6 